\title{
CYTOGENETIC TOXICITY EFFECTS OF LOCAL PURSLANE (Portulaca oleracea) LEAF CRUDE EXTRACTS ON NORMAL AND CANCER CELL LINES in Vitro
}

\section{ZAKARIA A.S. AND HAZHA J.H.*}

College of Education, Science Departments, Biology Department Research Center, University Salahaddin, Hawler, Kurdistan Region, Iraq. ${ }^{*}$ Corresponding Author: Email- hajajml@yahoo.com

Received: April 02, 2013; Accepted: April 15, 2013

\begin{abstract}
-
Aims: The present study was carried out to evaluate the cytogenetic toxicity effects of aqueous and ethanol crude extracts of the leaf of Portulaca oleracea L. against two malignant cell lines which were Murine mammary adenocarcinoma (AMN3), human Rhabdomyosarcoma $(\mathrm{RD})$ and one normal cell line which was kidney epithelium of African green monkey (Vero). Also the study included the antiproliferative effects of aqueous and ethanol crude extracts of $P$. oleracea leaf on the mitotic index (cell division) of Vero, AMN3 and RD cell lines In vitro.

Study Design: Cell based assay.

Place and Duration: Research center, University Salahaddin, Hawler, Kurdistan Region, Iraq, between 2010-2012.

Methodology: After plant sample treatment were observed and have reported through several assays such as trypan blue exlusion assay for cell viability, cytotoxicity assay by crystal violet and mitotic index assay.

Result and Conclusion: The aqueous crude extract was found to be more effective antiproliferate agent than the ethanol crude extract. Both extracts exhibited time-dependent cytotoxic effects against AMN3 and RD cancer cell lines. In which AMN3 was more sensitive to the extracts than RD. All concentrations of aqueous extract were affected AMN3 cell line at $72 \mathrm{Hrs}$. of exposure, but for ethanol extract the last dose $(0.01 \mu \mathrm{g} / \mathrm{ml})$ was not effective. While the Vero normal cell line showed resistance toward all concentrations of both extracts except the first dose $(10000 \mu \mathrm{g} / \mathrm{ml})$, at all time of exposure $(24,48$ and 72$) \mathrm{Hrs}$.

Also the antiproliferative effects of aqueous and ethanol crude extracts of Portulaca oleracea leaf were tested for mitotic index for Vero, AM$\mathrm{N} 3$ and RD cell lines in vitro after being treated to the extracts at (10000 and 1000$) \mu \mathrm{g} / \mathrm{ml}$ for three times of exposure (24, 48 and 72$) \mathrm{Hrs}$. It is revealed that the reduction in mitotic index in both cancer cell lines (AMN3 and RD) were found especially at 72 Hrs. of exposure, in which both crude extracts had the same effects on cell division, and showed time-dependent inhibitory effects. But the reduction of mitotic index in Vero normal cell line has been less noted, especially at 24 and $48 \mathrm{Hrs}$. of exposure. But at the $72 \mathrm{Hrs}$. of exposure showed some reduction in cell divisions when compared to the control.
\end{abstract}

Keywords- Portulaca oleracea, cytotoxicity, Mitotic index, Vero cell, RD cell and AMN3 cell

Citation: Zakaria A.S. and Hazha J.H. (2013) Cytogenetic Toxicity Effects of Local Purslane (Portulaca oleracea) Leaf Crude Extracts on Normal and Cancer Cell Lines in Vitro. International Journal of Drug Discovery, ISSN: 0975-4423 \& E-ISSN: 0975-914X, Volume 5, Issue 1, pp.$173-180$.

Copyright: Copyright@2013 Zakaria A.S. and Hazha J.H. This is an open-access article distributed under the terms of the Creative Commons Attribution License, which permits unrestricted use, distribution and reproduction in any medium, provided the original author and source are credited.

\section{Introduction}

Cancer is a genetic disease. It is characterized by unrestrained growth and reproduction of cells, loss of contact inhibition, and eventually metastasis. All of these changes represent underlying mutation or in appropriate expression of genes involved in the control of the cell cycle and related processes [10]. The bombardment of Halabja city in Iraqi Kurdistan region in 1988 with chemical weapons, caused more than 5000 martyrs and 10000 injury victim survivors are still suffering from a variety of health complains, which include cancers, and other health complains like respiratory, ophthalmological, dermatological, reproductive, and immunological complains [4]. It is widely held that $(80-90 \%)$, of human cancers may be attributable to environmental, lifestyle factors such as tobacco, alcohol, and dietary habits [9,12].

Portulaca oleracea $L$. (Purslane) has been used as a kind of food and medicinal plant for thousands of years in China. $P$. oleracea is very important because of its special medical function and all its therapeutic values are attributed to the presence of many biologically active compounds which include; flavonoids (Apigenin, kaempferol, quercetin, luteolin, myricetin, genistein, and genistin), Alkaloids, Coumarins, anthraquinone glycoside, cardiac glycoside, and high content of $\omega-3$ fatty acids [13]. 


\section{Material and Methods}

\section{Plant Collections}

The vegetative part of Portulaca oleraceae was collected from Khabat / Hawler (Erbil) city-Kurdistan region/ Iraq in August 2010. The plant was washed then the leaves were separated and left to dry at room temperature in the shade for nearly three weeks. Dried leaves were ground to fine powder. Using blender then passed through fine pored mesh sieve to provide homogeneous powder.

\section{Plant Classification}

The plant was classified by botanist in the biology department of college of education, scientific departments

$$
\begin{aligned}
& \text { Kingdom- Plantae (Plants) } \\
& \text { Sub kingdom- Tracheobionta (Vascular Plants) } \\
& \text { Division- Spermatophyta (Seed Plant) } \\
& \text { Sub Division- Angiospermae } \\
& \text { Class- Dicotyledoneae } \\
& \text { Order- Caryophyllales } \\
& \text { Family- Portulacaceae } \\
& \text { Genus- Portulaca } \\
& \text { Species- P. olaracea L. [19]. }
\end{aligned}
$$

\section{Aqueous Extract Preparations}

Fifty grams of macerated dried leaves were placed in $500 \mathrm{ml}$ volumetric flask then $400 \mathrm{ml}$ of deionized distilled water (DDW), added [5]. The volumetric flask was incubated in Ultrasonic bath for two hours [2]. Then the suspension was filtered through a clean gauze and then through a Bückner funnel several times. The residues re extracted for 48 and then 72 hours. The filtrations were performed daily, until the solution appeared to be colorless. The solution was collected in a clean bottle, and then dried in rotary evaporator at 40 ${ }^{\circ} \mathrm{C}$. This final crude extract stored at $-20^{\circ} \mathrm{C}$ until using in the experiment.

\section{Ethanol Extracts Preparation}

The ethanol extract of Portulaca oleraceae leaf was prepared as the same way as aqueous extract in (3. 2. 3), except of using $80 \%$ ethyl alcohol instead of DDW [5]. From 100 grams of plant powder 30 grams of aqueous crude extract were obtained, and 18 grams of ethanol crude extract obtained from other 100 grams of plant powder.

\section{Cell Lines}

Vero is the normal cell line was initiated from kidney of a normal adult African green monkey (Cercopitecus aethiops) on 27th March 1962, by Yasummura and Kawakita at the Chiba University, Japan. The AMN3 cancer cell line was derived from spontaneous mammary adenocarcinoma from female Balb/ $\mathrm{C}$ mice, and RD human cancer cell line was derived from a biopsy specimen obtained from pelvic rhabdomyosarcoma. All the cell lines were supplied by Tissue Culture Unit/ Iraqi Center for Cancer and Medical Genetic Research (ICCMGR, Baghdad/ Iraq) then maintained on MEM, and RPMI media with $10 \%$ of fetal bovine serum culture, $1 \%$ penicillinStreptomycin, cells were incubated at $37^{\circ} \mathrm{C}$ in a humidified atmosphere of $5 \% \mathrm{CO}_{2}$ in air.

\section{Viable Cell Counting}

Viable cell counting, accomplished by using trypan blue exclusion.
Dead cells unlike viable cells take up trypan blue within a few seconds making them easily distinguishable under the microscope from viable cells which were metabolitically alive had a cell membrane that was active selective in the materials that pass in to the cytoplasm.

\section{Cell Growths Assay}

The dry crud extracts were dissolved in maintenance media were used to obtain serial dilutions of $(10.000 \mu \mathrm{g} / \mathrm{ml}, 1000 \mu \mathrm{g} / \mathrm{ml}, 100 \mu \mathrm{g} /$ $\mathrm{ml}, 10 \mu \mathrm{g} / \mathrm{ml}, 1 \mu \mathrm{g} / \mathrm{ml}, 0.1 \mu \mathrm{g} / \mathrm{ml}, 0.01 \mu \mathrm{g} / \mathrm{ml}$ ) and $0 \mu \mathrm{g} / \mathrm{ml}$ as a control to study the effects of aqueous and ethanolic crude extracts on different cell lines. Cell monolayer were trypsinized washed with PBS buffer, Cells cultured (50000 cells/ ml for AMN3, 65000 cells/ $\mathrm{ml}$ for RD and 50000 cells/ $\mathrm{ml}$ for Vero) in the microtitration plate were exposed to a range of plant extract concentrations during the log phase of growth and the effect was determined of optical density of solution was measured at $492 \mathrm{~nm}$ using a microplate reader (ELISA).

\section{Mitotic Index}

The number of cells which arrested in the Metaphase were counted and also the total number of cells (1000 cells were counted) [14], [6], then the mitotic index was calculated as follow:

$$
\text { Mitotic index }(\%)=\frac{\text { Number of cells in mitotic phase }}{\text { Total number of cells }} \times 100
$$

\section{Statistical Analysis}

The results were analyzed with a prepared program of SPSS, version 18 [15]. Factorial experiment with a completely randomized design (CRD) were used for the reason of different factors; such as two types of crude extracts; (aqueous and ethanol), three types of cell lines; Vero (normal), AMN3 and RD (cancer), three periods; (24, 48 and 72) Hrs. the eight concentrations of the extracts; $(0 \mu \mathrm{g} /$ $\mathrm{ml}$ as control, $10000 \mu \mathrm{g} / \mathrm{ml}, 1000 \mu \mathrm{g} / \mathrm{ml}, 100 \mu \mathrm{g} / \mathrm{ml}, 10 \mu \mathrm{g} / \mathrm{ml}, 1 \mu \mathrm{g} /$ $\mathrm{ml}, 0.1 \mu \mathrm{g} / \mathrm{ml}$ and $0.01 \mu \mathrm{g} / \mathrm{ml}$ ) and five replications for each concentrations.

\section{Results and Discussion \\ Cell Growth Assay \\ The Effect of Different Concentrations of Aqueous and Ethanol Crude Extracts of $P$. oleracea on (Vero, AMN3 and RD) Cell Lines in Vitro}

[Fig-1] shows the mean of optical densities of aqueous crude extract on the cell lines (Vero, AMN3 and RD) at $24 \mathrm{Hrs}$. exposure revealing the reduction of the viability of cell culture. $\mathrm{RD}$ cell lines was more sensitive to the plant extract in the first three concentrations $(10000 \mu \mathrm{g} / \mathrm{ml}, 1000 \mu \mathrm{g} / \mathrm{ml}$, and $100 \mu \mathrm{g} / \mathrm{ml})$ While AMN3 more than $\mathrm{RD}$, in the fourth concentration also, if they compared to their controls $(0 \mu \mathrm{g} / \mathrm{ml})$. But in the four last concentrations, $(10,1,0.1$ and 0.01) $\mu \mathrm{g} / \mathrm{ml}$, the RD cancer cells not changed. But the Vero cells were slightly sensitive to the first concentration $(10000 \mu \mathrm{g} / \mathrm{ml})$. The [Fig-2] shows the effect of ethanol crude extract, nearly had the same effect, but AMN3 cells were more sensitive than RD, they inhibited by most of the concentrations, while RD was resistant in the last three concentrations $(1,0.1$ and 0.01$) \mu \mathrm{g} / \mathrm{ml})$. But Vero cells were sensitive in the first concentration $(10000 \mu \mathrm{g} / \mathrm{ml})$ only, if compared to the control.

In [Fig-3] Shows the effect of aqueous crude extract of $P$. oleracea at $48 \mathrm{Hrs}$. of exposure showing no important changes in Vero normal cell line except in the first concentration $(10000 \mu \mathrm{g} / \mathrm{ml})$, if com- 
pared to the control. While AMN3 cancer cell line was more sensitive to all concentrations except the final $(0.01 \mu \mathrm{g} / \mathrm{ml})$. But RD cancer cells were resistant to the last three concentrations $(1 \mu \mathrm{g} / \mathrm{ml}$, $0.1 \mu \mathrm{g} / \mathrm{ml}$, and $0.01 \mu \mathrm{g} / \mathrm{ml}$ ). Also in the [Fig-4] by the use of ethanol extract at the $48 \mathrm{Hrs}$. of exposure. The Vero cells were inhibited it's growth with the first $(10000 \mu \mathrm{g} / \mathrm{ml})$ and fifth $(1 \mu \mathrm{g} / \mathrm{ml})$ concentrations. But the two cancer cells were showed their sensitivities especially AMN3 in the first four $(10000,1000,100,10) \mu \mathrm{g} / \mathrm{ml}$, and sixth $(0.1 \mu \mathrm{g} / \mathrm{ml})$ concentrations, but RD cancer cells like aqueous extract were inhibited their growths in the first four $(10000,1000,100,10)$ $\mu \mathrm{g} / \mathrm{ml}$ concentrations. But in the last three concentrations $(1,0.1$, $0.01) \mu \mathrm{g} / \mathrm{ml}$ of the RD cells have no important changes observed. But at the $72 \mathrm{Hrs}$. of exposure, in the use of aqueous extract the growth of AMN3 cancer cell line was inhibited with all concentrations. Also the RD cells were inhibited by most of the concentrations except the last two $(0.1,0.01) \mu \mathrm{g} / \mathrm{ml}$ concentrations, while the Vero normal cell line was inhibited slightly by the first two $(10000$, 1000) $\mu \mathrm{g} / \mathrm{ml}$, concentrations, as showing in the [Fig-5]. But in the [Fig-6] by the use of ethanol extracts the Vero cells were sensitive to the first concentration $(10000 \mu \mathrm{g} / \mathrm{ml})$ only. But the growth of AM$\mathrm{N} 3$ cancer cell line was inhibited by all concentrations just the last $(0.01 \mu \mathrm{g} / \mathrm{ml})$ one. While the RD cancer cell line was inhibited it's growth with the first three $(10000,1000,100) \mu \mathrm{g} / \mathrm{ml}$, and fifth $(1 \mu \mathrm{g} /$ $\mathrm{ml}$ ) concentrations, if they compared to their controls.

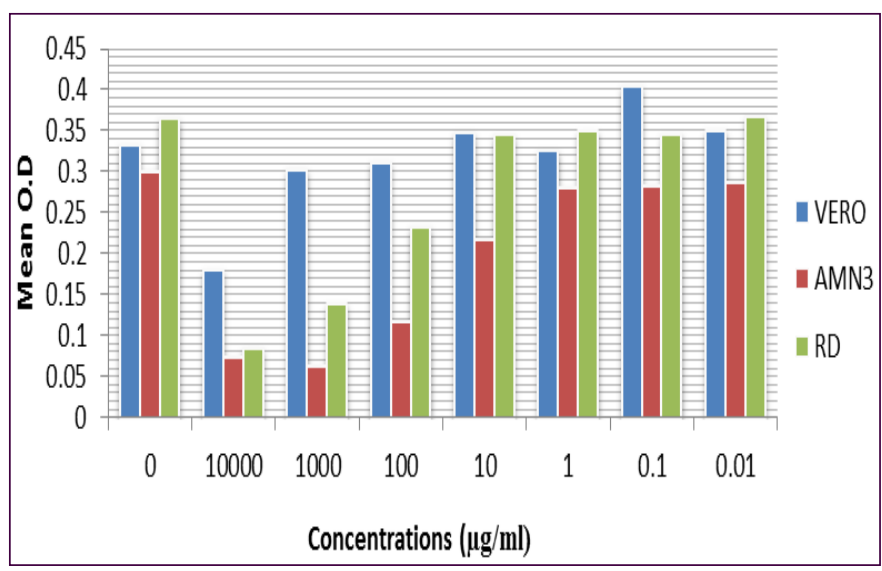

Fig. 1- Mean of optical densities of (Vero, AMN3 and RD) cell lines after exposure to different concentrations of aqueous crude extract of $P$. oleracea for $24 \mathrm{Hrs}$. of exposure.

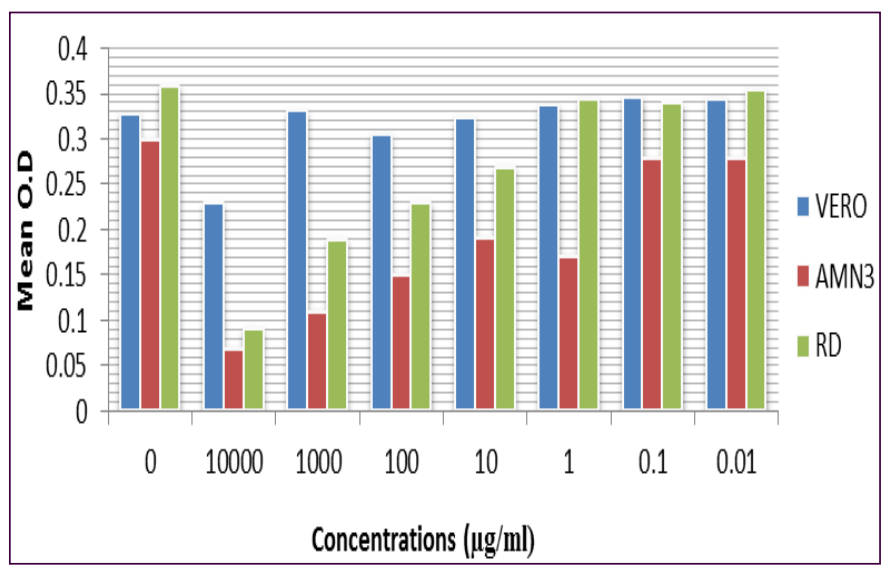

Fig. 2- Mean of optical densities of (Vero, AMN3 and RD) cell lines after exposure to different concentrations of ethanol crude extract of $P$. oleracea for $24 \mathrm{Hrs}$. of exposure

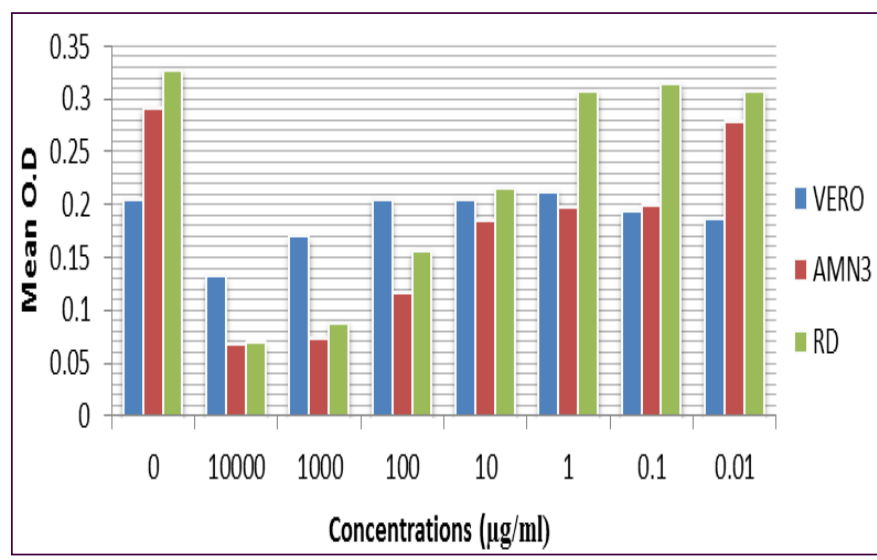

Fig. 3- Mean of optical densities of (Vero, AMN3 and RD) cell lines after exposure to different concentrations of aqueous crude extract of $P$. oleracea for $48 \mathrm{Hrs}$. of exposure

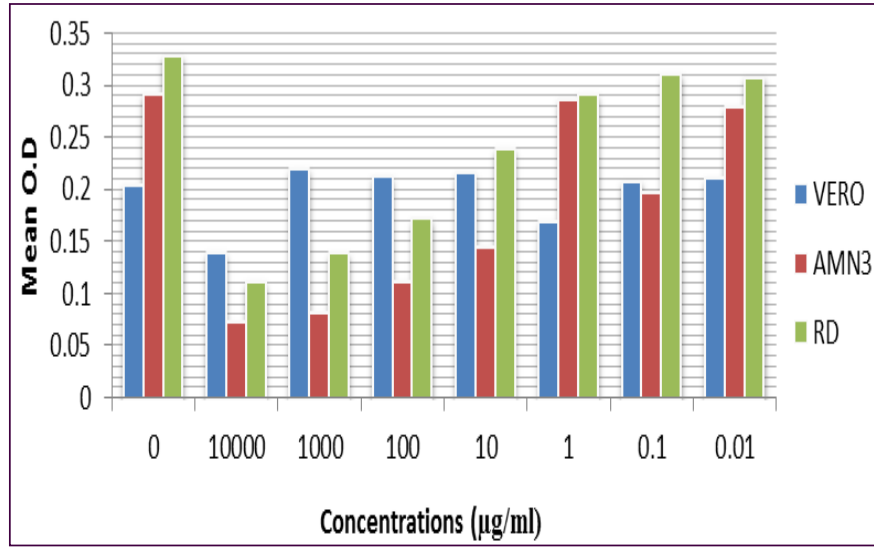

Fig. 4- Mean of optical densities of (Vero, AMN3 and RD) cell lines after exposure to different concentrations of ethanol crude extract of $P$. oleracea for $48 \mathrm{Hrs}$. of exposure

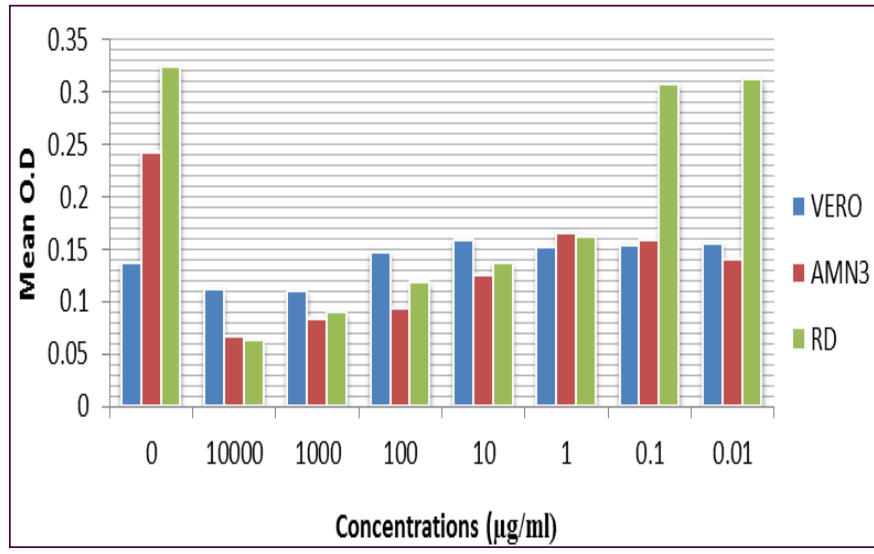

Fig. 5- Mean of optical densities of (Vero, AMN3 and RD) cell lines after exposure to different concentrations of aqueous crude extract of $P$. oleracea for $72 \mathrm{Hrs}$. of exposure

It is revealed that in all six figures; the two cancer cell lines AMN3 and RD were more inhibited their growths with aqueous extract than ethanol extract, and slightly changes were recorded to Vero normal cell line especially at the first higher concentration. And the reduction of cell viability was increased by increasing concentrations, which were dose dependent manner. And the reduction of viability of cell culture also increased by increasing time of exposure. 


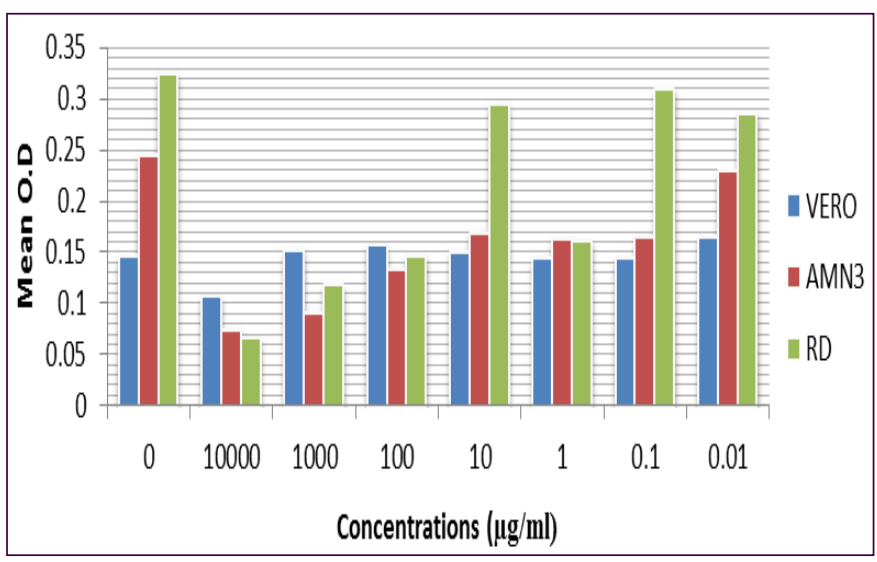

Fig. 6- Mean of optical densities of (Vero, AMN3 and RD) cell lines after exposure to different concentrations of ethanol crude extract of $P$. oleracea for $72 \mathrm{Hrs}$. of exposure
Results of the present study as in [Table-1] showed that most concentrations (doses) were effective against two cancer cell lines (AMN3 and RD) especially at $72 \mathrm{Hrs}$. of aqueous and ethanolic extracts. While the concentration $(10.000 \mu \mathrm{g} / \mathrm{ml})$ was affect the Vero (normal cell line), but the other concentrations were safe to the normal cell line. The inhibition activity of both extracts (aqueous and ethaolic) against AMN3 cancer cells were more than against RD cancer cells. It means AMN3 was more sensitive to aqueous and ethanolic crude extracts than $\mathrm{RD}$, this can be attributed to the sensitivity of AMN3 to the extracts more than RD, and/ or may be due to sensitivity of death receptors of AMN3 plasma membrane to the active compounds (especially flavonoids) in both extracts of $P$. oleracea. and $\mathrm{RD}$ receptors may be less sensitive to the compounds. But Vero (normal) cell line was resistant toward all concentrations of both extracts except the first concentration $(10000 \mu \mathrm{g} /$ $\mathrm{ml})$. So the Vero (normal) cell line was used for comparison with cancer cell lines.

Table 1- Mean \pm S.E of the optical densities for Vero, AMN3 and RD cell lines respectively after treatment by different concentrations of aqueous and ethanol crude extracts in a cell growth assay in vitro

\begin{tabular}{|c|c|c|c|c|c|c|c|}
\hline \multirow[b]{2}{*}{ Periods } & \multirow[b]{2}{*}{$\begin{array}{l}\text { Conc. } \\
\mu \mathrm{g} / \mathrm{ml}\end{array}$} & \multicolumn{6}{|c|}{ Cell Lines } \\
\hline & & Vero & $\begin{array}{c}\text { Ethanol Extract } \\
\text { AMN3 }\end{array}$ & RD & Vero & $\begin{array}{c}\text { Aqueous Extract } \\
\text { AMN3 }\end{array}$ & RD \\
\hline \multirow[t]{8}{*}{24 Hrs. } & $\mathrm{CO}$ & $0.3328 \pm 0.0168$ & $0.3008 \pm 0.0043$ & $0.3644 \pm 0.0012$ & $0.3286 \pm 0.0147$ & $0.3008 \pm 0.0043$ & $0.3600 \pm 0.0053$ \\
\hline & $\mathrm{C} 1$ & $0.1798 \pm 0.0042^{* *}$ & $0.0736 \pm 0.0031^{* *}$ & $0.0838 \pm 0.0104^{* *}$ & $0.2298 \pm 0.0147^{* *}$ & $0.0686 \pm 0.0048^{* *}$ & $0.0910 \pm 0.0073^{* *}$ \\
\hline & $\mathrm{C} 2$ & $0.3029 \pm 0.0042^{* *}$ & $0.0626 \pm 0.0014^{* *}$ & $0.1388 \pm 0.0150^{* *}$ & $0.3322 \pm 0.0337$ & $0.1106 \pm 0.0061^{* *}$ & $0.1902 \pm 0.0090^{* *}$ \\
\hline & C3 & $0.3116 \pm 0.0085^{\star *}$ & $0.1166 \pm 0.0092^{* *}$ & $0.2322 \pm 0.0270^{* *}$ & $0.3060 \pm 0.0329^{* *}$ & $0.1516 \pm 0.0184^{* *}$ & $0.2308 \pm 0.0228^{* *}$ \\
\hline & $\mathrm{C} 4$ & $0.3470 \pm 0.0339$ & $0.2170 \pm 0.0043^{* *}$ & $0.3446 \pm 0.0101$ & $0.3250 \pm 0.0399$ & $0.1918 \pm 0.0122^{* *}$ & $0.2700 \pm 0.0168^{* *}$ \\
\hline & C5 & $0.3252 \pm 0.0214$ & $0.2798 \pm 0.0146^{* *}$ & $0.3494 \pm 0.0040$ & $0.3384 \pm 0.0231$ & $0.1718 \pm 0.0156^{* *}$ & $0.3454 \pm 0.0151$ \\
\hline & C6 & $0.3540 \pm 0.0236$ & $0.2828 \pm 0.0094^{* *}$ & $0.3458 \pm 0.0142$ & $0.3462 \pm 0.0275$ & $0.2796 \pm 0.0110^{* *}$ & $0.3398 \pm 0.0082$ \\
\hline & $\mathrm{C} 7$ & $0.3506 \pm 0.0169$ & $0.2876 \pm 0.0092$ & $0.3662 \pm 0.0099$ & $0.3454 \pm 0.0281$ & $0.2800 \pm 0.0209^{* *}$ & $0.3554 \pm 0.0188$ \\
\hline \multirow[t]{8}{*}{$48 \mathrm{Hrs}}$. & $\mathrm{CO}$ & $0.2036 \pm 0.0048$ & $0.2912 \pm 0.0044$ & $0.3270 \pm 0.0044$ & $0.2036 \pm 0.0048$ & $0.2912 \pm 0.0044$ & $0.3270 \pm 0.0044$ \\
\hline & $\mathrm{C} 1$ & $0.1316 \pm 0.0070^{* *}$ & $0.0670 \pm 0.0082^{* *}$ & $0.0688 \pm 0.0021^{* *}$ & $0.1386 \pm 0.0079^{* *}$ & $0.0718 \pm 0.0043^{* *}$ & $0.1108 \pm 0.0229^{* *}$ \\
\hline & $\mathrm{C} 2$ & $0.1694 \pm 0.0065^{\star *}$ & $0.0736 \pm 0.0103^{* *}$ & $0.0880 \pm 0.0198 * *$ & $0.2188 \pm 0.0081$ & $0.0804 \pm 0.0104^{* *}$ & $0.1382 \pm 0.0094^{* *}$ \\
\hline & C3 & $0.2050 \pm 0.0099$ & $0.1158 \pm 0.0198^{* *}$ & $0.1556 \pm 0.0293^{* *}$ & $0.2114 \pm 0.0075$ & $0.1110 \pm 0.0098^{* *}$ & $0.1710 \pm 0.0205^{\star *}$ \\
\hline & C4 & $0.2048 \pm 0.0133$ & $0.1846 \pm 0.0116^{* *}$ & $0.2142 \pm 0.0105^{\star *}$ & $0.2146 \pm 0.0084$ & $0.1438 \pm 0.0011^{* *}$ & $0.2378 \pm 0.0046^{\star *}$ \\
\hline & C5 & $0.2122 \pm 0.0231$ & $0.1972 \pm 0.0043^{* *}$ & $0.3064 \pm 0.0115$ & $0.1686 \pm 0.0074^{* *}$ & $0.2854 \pm 0.0147$ & $0.2902 \pm 0.0058^{* *}$ \\
\hline & C6 & $0.1934 \pm 0.0080$ & $0.1982 \pm 0.0021^{* *}$ & $0.3144 \pm 0.0217$ & $0.2066 \pm 0.0062$ & $0.1954 \pm 0.0050^{* *}$ & $0.3096 \pm 0.0027$ \\
\hline & $\mathrm{C} 7$ & $0.1854 \pm 0.0092$ & $0.2780 \pm 0.0042$ & $0.3068 \pm 0.0035$ & $0.2098 \pm 0.0069$ & $0.2784 \pm 0.0120$ & $0.3069 \pm 0.0085$ \\
\hline \multirow[t]{8}{*}{72 Hrs. } & $\mathrm{CO}$ & $0.1374 \pm 0.0039$ & $0.2436 \pm 0.0035$ & $0.3256 \pm 0.0076$ & $0.1454 \pm 0.0039$ & $0.2436 \pm 0.0035$ & $0.3246 \pm 0.0080$ \\
\hline & $\mathrm{C} 1$ & $0.0618 \pm 0.0059^{* *}$ & $0.0666 \pm 0.0012^{* *}$ & $0.0632 \pm 0.0090^{* *}$ & $0.0702 \pm 0.0032^{\star *}$ & $0.0742 \pm 0.0031^{* *}$ & $0.0666 \pm 0.0209^{* *}$ \\
\hline & $\mathrm{C} 2$ & $0.1008 \pm 0.0098^{* *}$ & $0.0832 \pm 0.0052^{* *}$ & $0.0906 \pm 0.0088^{* *}$ & $0.1520 \pm 0.0049$ & $0.0900 \pm 0.0042^{* *}$ & $0.1170 \pm 0.0157^{* *}$ \\
\hline & C3 & $0.1478 \pm 0.0040$ & $0.0938 \pm 0.0068^{* *}$ & $0.1186 \pm 0.0311^{* *}$ & $0.1568 \pm 0.0069$ & $0.1330 \pm 0.0155^{\star *}$ & $0.1462 \pm 0.0230^{* *}$ \\
\hline & C4 & $0.1596 \pm 0.0037$ & $0.1256 \pm 0.0028^{* *}$ & $0.1372 \pm 0.0173^{* *}$ & $0.1498 \pm 0.0055$ & $0.1686 \pm 0.0131^{* *}$ & $0.2942 \pm 0.0198^{* *}$ \\
\hline & C5 & $0.1520 \pm 0.0017$ & $0.1668 \pm 0.0024^{* *}$ & $0.1628 \pm 0.0280^{\star *}$ & $0.1438 \pm 0.0041$ & $0.1628 \pm 0.0118^{* *}$ & $0.1608 \pm 0.0113^{* *}$ \\
\hline & C6 & $0.1542 \pm 0.0023$ & $0.1590 \pm 0.0049^{* *}$ & $0.3084 \pm 0.0195$ & $0.1440 \pm 0.0074$ & $0.1646 \pm 0.0111^{* *}$ & $0.3094 \pm 0.0292$ \\
\hline & $\mathrm{C} 7$ & $0.1566 \pm 0.0036$ & $0.1404 \pm 0.0244^{* *}$ & $0.3130 \pm 0.0324$ & $0.1642 \pm 0.0024$ & $0.2286 \pm 0.0073$ & $0.2856 \pm 0.0268^{* *}$ \\
\hline LSD & & 0.021 & 0.0148 & 0.021 & 0.021 & 0.014 & 0.021 \\
\hline
\end{tabular}

C0 $0 \mu \mu \mathrm{g} / \mathrm{ml}$ (Control), C1= $10.000 \mu \mathrm{g} / \mathrm{ml}, \mathrm{C2}=1000 \mu \mathrm{g} / \mathrm{ml}$, C3=100 $\mu \mathrm{g} / \mathrm{ml}, \mathrm{C} 4=10 \mu \mathrm{g} / \mathrm{ml}, \mathrm{C5}=1 \mu \mathrm{g} / \mathrm{ml}, \mathrm{C} 6=0.1 \mu \mathrm{g} / \mathrm{ml}, \mathrm{C} 7=0.01 \mu \mathrm{g} / \mathrm{ml}$

Also the results showed that the growth inhibition of the aqueous and ethanolic crude extracts of $P$. oleracea which exhibited timedependent inhibitory effects on AMN3 and RD cancer cell lines. The viability reaches it's lowest, with extended time of exposure for 48 and $72 \mathrm{Hrs}$. Also concentration of active compounds of both extracts were needed to reduce the cell viability, the higher concentrations were strongly affected the AMN3 and RD cancer cell lines. Besides the aqueous extract of $P$. oleracea at $72 \mathrm{Hrs}$. of exposure had the highest inhibitory effect against cancer cell lines than ethanolic extract at any time of exposure. The higher doses at longer time of exposure had stronger inhibitory effect against cancer cell lines than lower doses at shorter time of exposure. Also the aqueous extract of $P$. oleracea in higher doses were stronger affected the cancer cells than ethanolic extract and lower doses. All these findings may due to more solubility of active compounds in water more than ethanol, and functioning of these compounds when they present at higher concentrations, and at longer time of exposure.

\section{Cytological Study}

The phenotypic characteristics of (Vero, AMN3 and RD) cell lines after exposed to aqueous and ethanolic crude extracts of $P$. oleraceae were evaluated by using inverted microscope. The results showed the different cytological changes such as chromatin condensation, pyknosis, karyorrhexis, cytoplasmic vaculation, cell shrinkage and cytoplasmic disruption and these changes were depended on the different concentrations of the plant extracts and the periods of exposure [Fig-7], [Fig-8], [Fig-9]. 


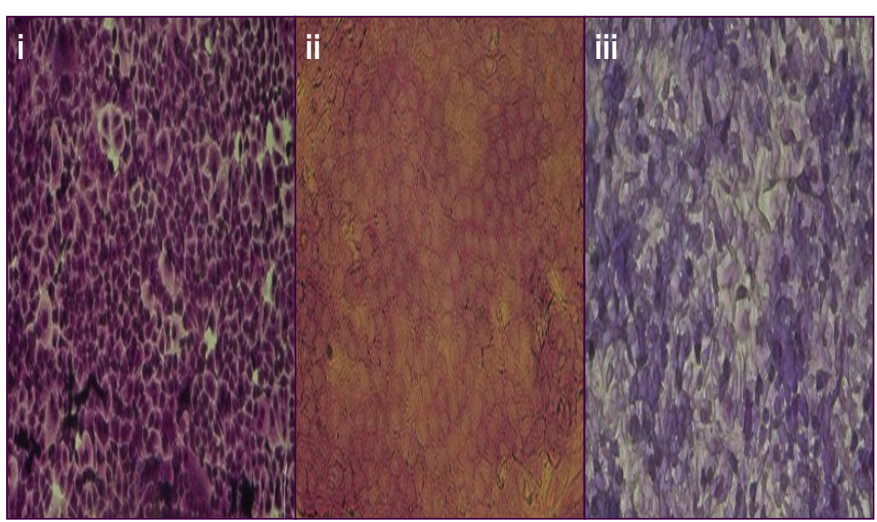

Fig. 7- (i, ii, iii) The untreated Vero (normal) cells, AMN3 and RD cancer cell lines tend to form a confluent monolayer respectively. The shape of AMN3 cancer cells was oval, while RD cancer cells appeared elongate to spindle in shape

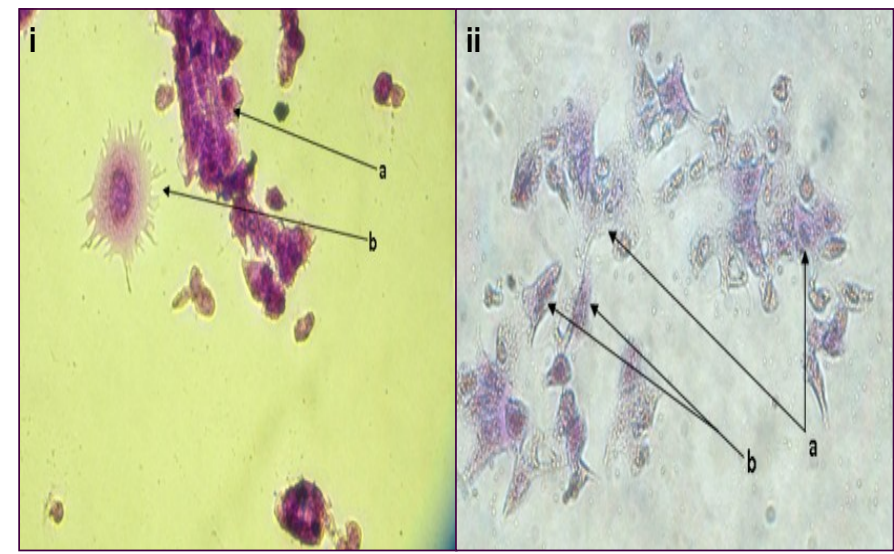

Fig. 8- (i) AMN3 cells treated by aqueous crude extract of $P$. oleracea $10000 \mu \mathrm{g} / \mathrm{ml}$ for $48 \mathrm{Hrs}$. Shows (a): Masses of the dead cells, (b): Disrupted apoptotic cells. (ii) AMN3 cells treated by aqueous extract of $P$. oleracea $10000 \mu \mathrm{g} / \mathrm{ml}$ for $72 \mathrm{Hrs}$. Shows (a): Completely dead cells (b): Cell shrinkage (400X Crystal violet)

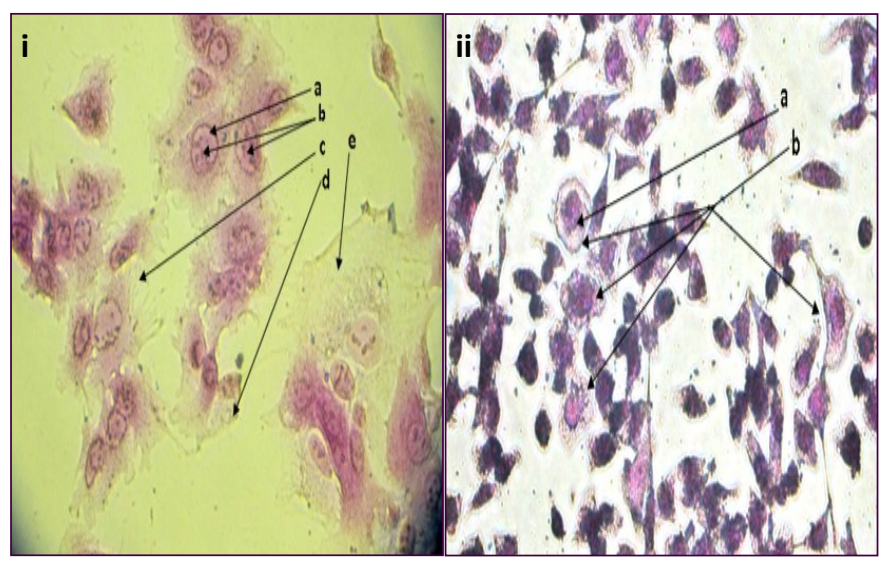

Fig. 9- (i) AMN3 cells treated by Ethanolic extract of $P$. oleracea $10000 \mu \mathrm{g} / \mathrm{ml}$ for $72 \mathrm{Hrs}$. Shows (a): pyknosis, (b): swelling and condensation of nuclear chromatin, (c): Disruption of plasma membrane, cytoplasm and karyorrhexis, (d): completely disruption of monolayer, (e): multinucleated giant cells, (ii) RD cells treated by ethanolic extract of $P$. oleracea $1000 \mu \mathrm{g} / \mathrm{ml}$ for $72 \mathrm{Hrs}$. Shows (a): pyknosis, (b): Cell swelling (400X Crystal violet)

The significant activity of aqueous and ethanolic crude extracts of $P$. oleracea are thought to be a result of the induction of cell death by apoptosis as our result indicate. Flavonoids would induce apoptosis in cancer cells as a desired strategy of controlling cancers [18]. Our results would support the previous studies especially DNA fragmentation, nuclear condensation, and cell shrinkage which were clearly observed, cytoplasmic disruption, cytoplasmic vaculation, pyknosis and karyorrhexis. Flavonoids may exert regulatory activities in cells through actions at different signal transduction pathways such as; cyclin dependent kinase (cdk), caspases, Bcl2 and Bax family members, epidermal growth factor/ epidermal growth factor receptor, phosphatidylinositol-3-kinase/ Akt, mitogen activated protein kinase (MAPK), and nuclear factor kappa $B$ (NFkB), which may affect cellular function by modulating genes or phosphorylating proteins [3]. Flavonoids also contribute to cancer prevention by other mechanisms such as radical scavenging, detoxification of mutagenic xenobiotics and inhibition of topoisomerase cyclin-dependent kinases, protein kinases including phosphotidylinositol 3-kinase. Flavonoids recently showed that inhibited fatty acid synthase (FAS) activity and lipogenesis, this effect is strongly associated with growth arrest and cell death. Blockage of FAS by the chemical inhibitors will inhibits proliferation and cytotoxic for various tumors cell lines in vitro and in vivo. Expression of FAS is markedly increased in various human cancers, including; prostate, breast, ovary, endometrium, colon and lung [1].

Aqueous crude extract of $P$. oleracea causes $50 \%$ cell death in the two (AMN3, RD) cancer cell lines tested. The best $I C_{50}$ values obtained were $(27.33,34.15$ and 38.50$) \mu \mathrm{g} / \mathrm{ml}$ for the three concentrations $(10000,1000$ and 100$) \mu \mathrm{g} / \mathrm{ml}$ respectively causing $50 \%$ of the AMN3 cancer cell line to die. But for RD cancer cell line the $\mathrm{IC}_{50}$ values were $(21.25,27.82$ and 39.43$) \mu \mathrm{g} / \mathrm{ml}$ for the three concentrations $(10000,1000$ and 0.1$) \mu \mathrm{g} / \mathrm{ml}$ respectively caused $\mathrm{RD}$ cancer cell to die, as in [Fig-10].

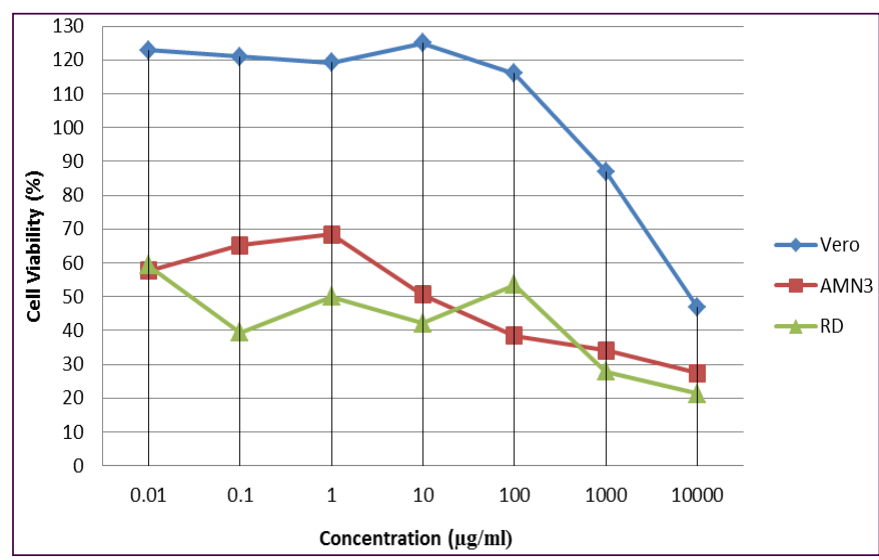

Fig. 10- IC $\mathrm{C}_{50}$ values for the cytotoxicity effects of $P$. oleracea aqueous crude extract on (Vero, AMN3 and RD) cell lines for 72 hours of exposure

In the [Fig-11], Ethanol crude extract of $P$. oleracea causes $50 \%$ cell death in the two (AMN3, RD) cancer cell lines tested. The best $\mathrm{IC}_{50}$ values obtained were $(30.45$ and 36.94$) \mu \mathrm{g} / \mathrm{ml}$ for the two concentrations (10000 and 1000$) \mu \mathrm{g} / \mathrm{ml}$ respectively causing $50 \%$ of the AMN3 cancer cell line to die. The $\mathrm{IC}_{50}$ values for $\mathrm{RD}$ cancer cell line were $(20.51$ and 35.67$) \mu \mathrm{g} / \mathrm{ml}$ for the two concentrations (10000 and 1000$) \mu \mathrm{g} / \mathrm{ml}$ respectively causing $50 \%$ RD cell death. But the $\mathrm{IC}_{50}$ values for the Vero normal cell line were (46.78 and 46.90) $\mu \mathrm{g} / \mathrm{ml}$ for aqueous and ethanol crude extracts respectively causing 50\% cell death except in the highest (10000) $\mathrm{\mu g} / \mathrm{ml}$ concentration. 


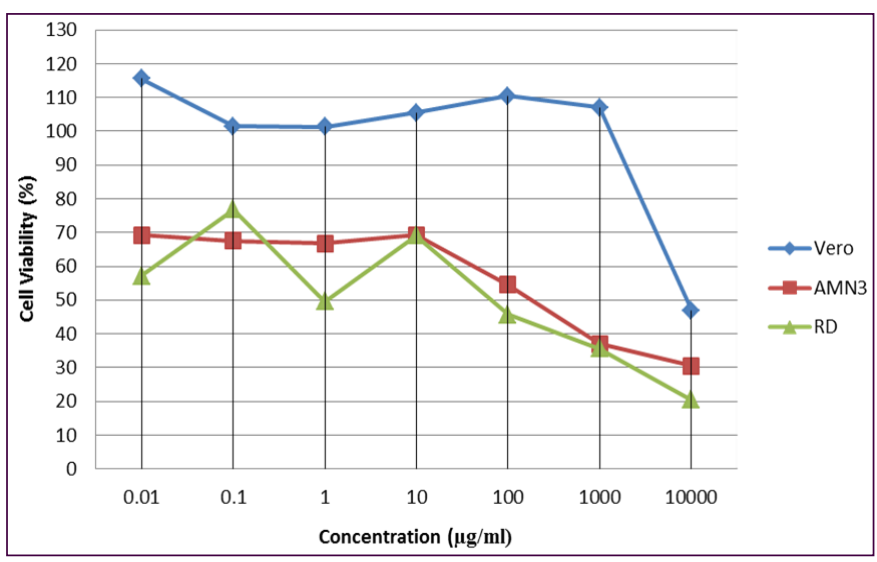

Fig. 11- $\mathrm{IC}_{50}$ values for the cytotoxicity effects of $P$. oleracea ethanol crude extract on (Vero, AMN3 and RD) cell lines for 72 hours of exposure

The Effect of Two Higher Concentrations of Aqueous and Ethanol Crude Extracts of $P$. oleracea on the Mitotic Index of Vero, AMN3 and RD Cell Lines

The [Fig-12] and [Fig-13], show the mean of mitotic index of (Vero, AMN3 and RD) cell lines. In which the cells were exposed to two higher concentrations $(10.000$ and 1000$) \mu \mathrm{g} / \mathrm{ml}$ of aqueous and ethanol crude extracts of $P$. oleracea for $24 \mathrm{Hrs}$.

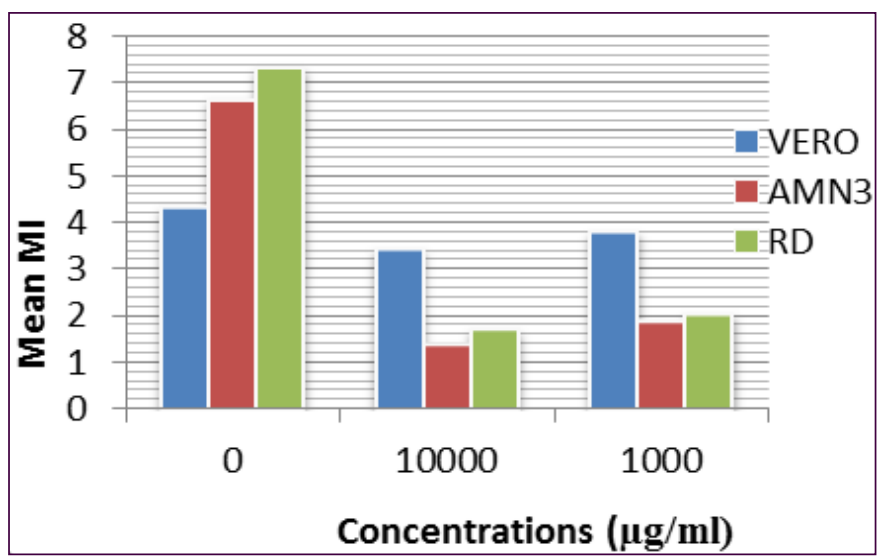

Fig. 12- Mean of mitotic index of (Vero, AMN3 and RD) cell lines after exposure to different concentrations of aqueous crude extract of $P$. oleracea for $24 \mathrm{Hrs}$.

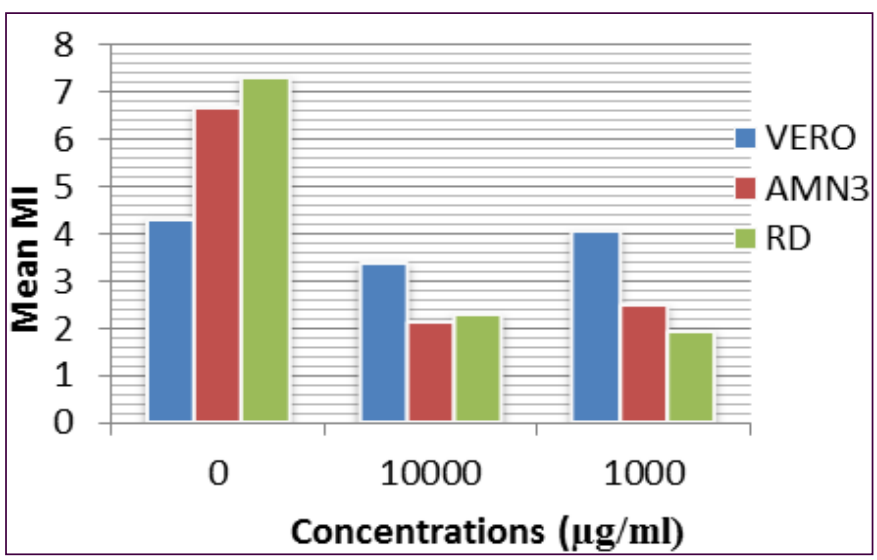

Fig. 13- Mean of mitotic index of (Vero, AMN3 and RD) cell lines after exposure to different concentrations of ethanol crude extract of $P$. oleracea for $24 \mathrm{Hrs}$.

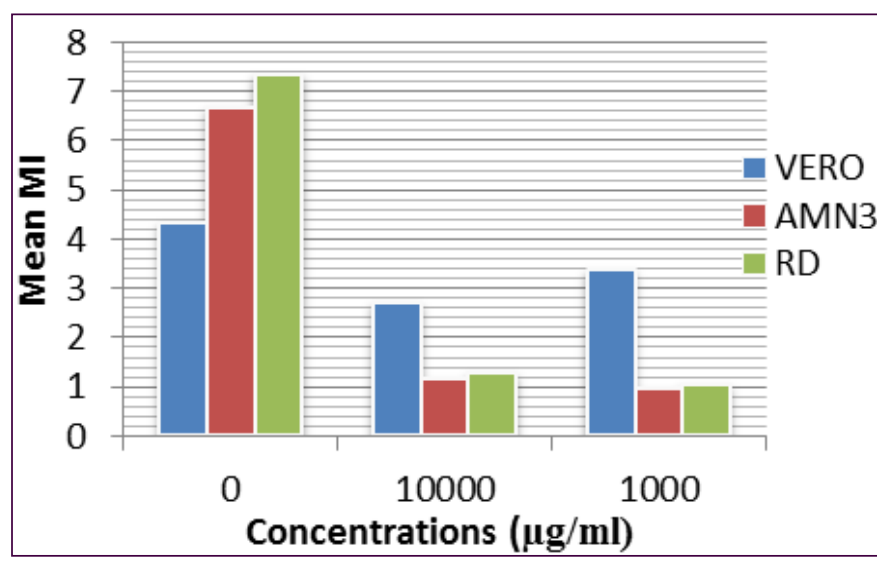

Fig. 14- Mean of mitotic index of (Vero, AMN3 and RD) cell lines after exposure to different concentrations of aqueous crude extract of $P$. oleracea for $48 \mathrm{Hrs}$.

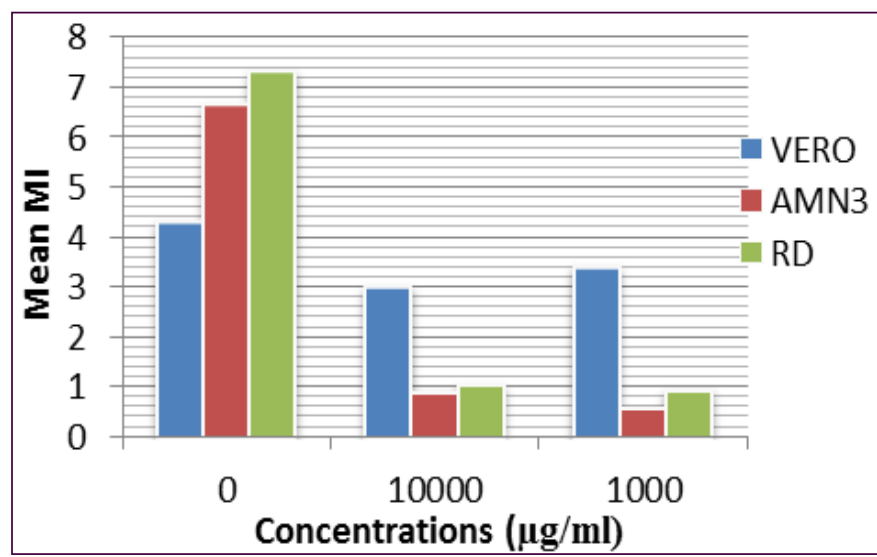

Fig. 15- Mean of mitotic index of (Vero, AMN3 and RD) cell lines after exposure to different concentrations of ethanol crude extract of $P$. oleracea for $48 \mathrm{Hrs}$.

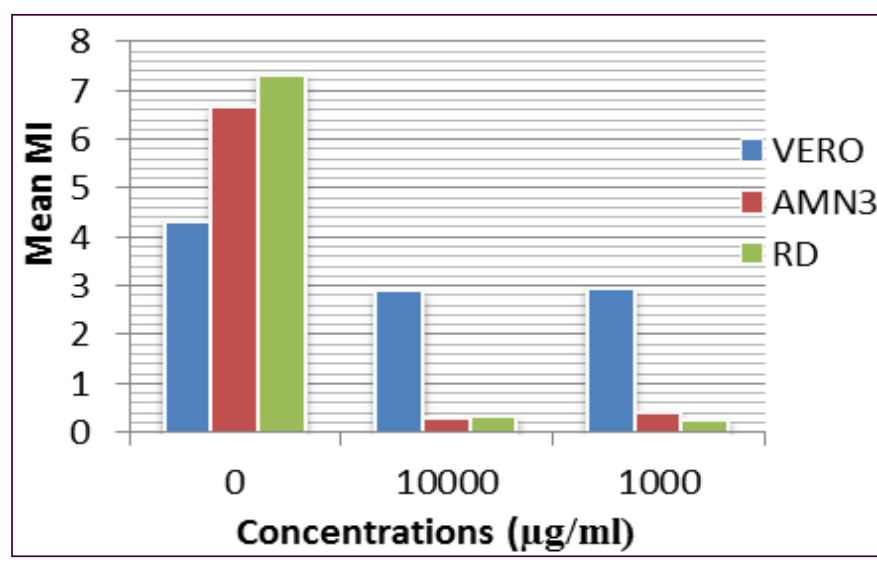

Fig. 16- Mean of mitotic index of (Vero, AMN3 and RD) cell lines after exposure to different concentrations of aqueous crude extract of $P$. oleracea for $72 \mathrm{Hrs}$.

In which the mitosis (cell division) of the two cancer cell lines (AMN3 and RD) were significantly $(P<0.01)$ decreased in aqueous extract more than ethanol extract. But the Vero (normal cell line) was slightly decreased and not affected at $1000 \mu \mathrm{g} / \mathrm{ml}$. if compared to their controls. In case of $48 \mathrm{Hrs}$. of exposure the cell division of two cancer cell lines AMN3 and RD were significantly $(P<0.01)$ decreased more than $24 \mathrm{Hrs}$. if compared to their controls, as shown in [Fig-14] and [Fig-15]. But in the $72 \mathrm{Hrs}$. of exposure of 
aqueous and ethanol crude extracts, the mitotic index (cell division) was high significantly $(P<0.01)$ affected and decreased in both $A M-$ N3 and RD cancer cell lines. And also Vero was slightly decreased. If they compared to their controls, as in [Fig-16] and [Fig-17].

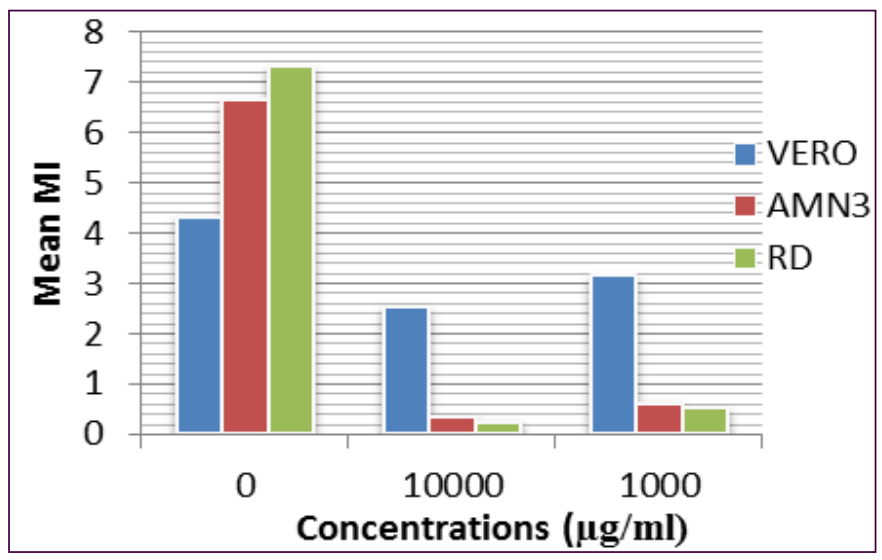

Fig. 17- Mean of mitotic index of (Vero, AMN3 and RD) cell lines after exposure to different concentrations of ethanol crude extract of $P$. oleracea for $72 \mathrm{Hrs}$.

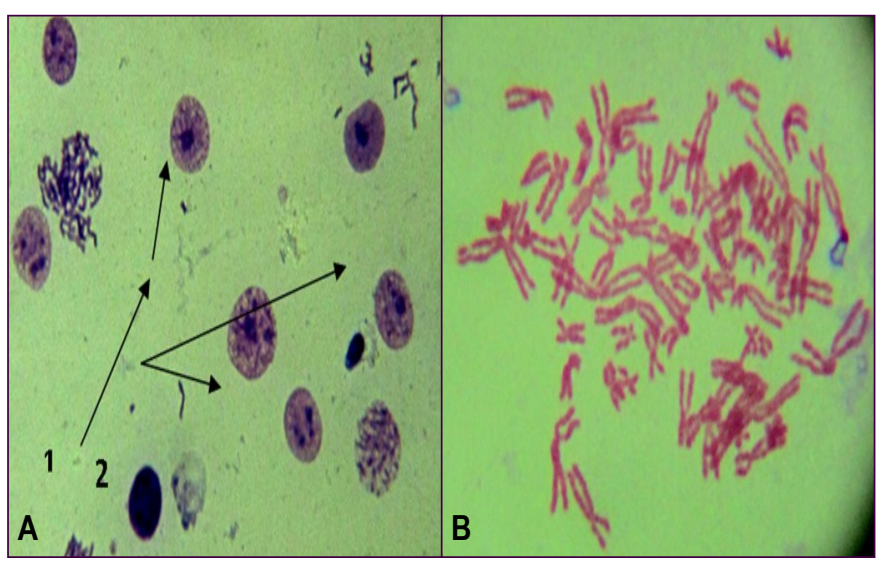

Fig. 18- A: Vero cells during (1): metaphase and (2): prophase counted for mitotic index (400 X). B: Chromosomes of Vero cells $(1000 \mathrm{X})$ untreated to plant extracts

\section{Cytogenetic Effect of Aqueous and Ethanolic Crude Extract of $P$. oleracea on Vero, AMN3 and RD Cell Lines in Vitro}

The study of mitotic index was used to determine the rate of cell division. In this study the first two higher concentrations $(10000 \mu \mathrm{g} /$ $\mathrm{ml}$ and $1000 \mu \mathrm{g} / \mathrm{ml}$ ) of aqueous and ethanolic crude extracts were tested on the three cell lines Vero (normal) cell line, and two cancer cell lines (AMN3 and RD) for three periods of exposure (24, 48 and 72) Hrs. In which the rate of cell division of Vero cell line was slightly decreased when exposed to the high dose of plant extract $10000 \mu \mathrm{g} / \mathrm{ml}$ for $72 \mathrm{Hrs}$. and $48 \mathrm{Hrs}$. of exposure. But at $24 \mathrm{Hrs}$. there were no any important changes in cell division. In which the aqueous extract was more effective than ethanolic extract, this is may be due to the high solubility of active compounds in water than ethanol. The Vero cell line was more resistant than AMN3 and RD cancer cell lines, because the cell division (mitosis) in AMN3 and RD cancer cells were highly decrease by both concentrations (10000 and 1000) $\mu \mathrm{g} / \mathrm{ml}$. of aqueous and ethanolic crude extracts, and for the three periods of exposure $(24,48$ and 72$) \mathrm{Hrs}$. especially at $72 \mathrm{Hrs}$. This was due to the effect of active constituents found in $P$. oleracea functioning as antiproliferative and apoptotic and cytotoxic agents, such as flavonoids, alkaloids, anthraquinones, coumarins, etc. It is demonstrated that dietary flavonoids inhibit the proliferation of various cancer cells and tumor growth in animal models, and protect against cancer induction in several human tissues [11]. Several flavonoids regulate the genes that are critical for the control of proliferation, cell cycle and apoptosis pathway in cancer cells. Recent reports demonstrated that apigenin and genistein caused a G2/ M arrest of the cell cycle in several human and murine cell lines. Quercetin has been shown to inhibit cell cycle progression at the G1-S phase in human gastric cancer cell line HGC-27 [8].

The molecular mechanism of cell cycle arrest by apigenin was conducted by inhibiting of cyclin B1 and phosphorylation of p34cdc2 protein in two mouse skin cancer keratinocyte cell lines (C50 and 308) and HL-60 human mylogenous leukemia cells. Since cyclin Bp34cdc2 complexes regulate $\mathrm{G} 2 / \mathrm{M}$ progression. Inactivation of cyclin $\mathrm{B}-\mathrm{p} 34 \mathrm{cdc2}$ is required for exit from mitosis and results from degradation of cyclin B [8]. Also apigenin arrests the cell cycle at the G2/ M phase accompanied by decrease of cyclin B1 in human colorectal cancer cells [19]. And induce p21 level resulting in cell cycle arrest and apoptosis in human prostate cancer LNCap cells [17].

Luteolin decrease DNA synthesis in human colon cancer cell line HF29 in a concentration dependent manner. Luteolin inhibited cyclin-dependent kinase (cdk) activity resulting in G1 arrest. And also promote G2/ M phase arrest in the cell cycle. This was happened in variety of cancers like; human thyroid cancer cell line, HL-60 human myloid leukemia, Miapaca-2 pancreatic tumor cells, HepG2 human hepatocellular carcinoma, luteolin induced a G1 cell cycle arrest in OCM-1 human melanoma cells, and G2/ M phase arrest in SW480 colon cancer [7].

\section{Conclusions}

1. From the results of the present study, the following conclusions could be considered:

2. Most concentrations were effective against two cancer cell lines especially at $72 \mathrm{Hrs}$. of exposure.

3. The AMN3 cancer cell line was the most sensitive to the inhibitory effects of aqueous and ethanolic crude extracts of $P$. oleracea. While the RD cancer cell line showed less response toward both extracts, especially at low concentrations.

4. Aqueous extract was more effective antiproliferative agent against two malignant cell lines as compared to ethanolic extract.

5. The Vero normal cell line was the most resistant cell line toward both extracts, except at higher concentrations, for all periods of exposure.

6. Both aqueous and ethanolic crude extracts of Portulaca oleracea had the potent inhibitory effects on mitotic index in both cancer cell lines and at all periods of exposure.

7. Active constituents of $P$. oleracea had the cytotoxic, apoptotic, antiproliferative and cell cycle arrest properties against the two (AMN3 and RD) cancer cell lines, and did not have any important effects toward the (Vero) normal cell line.

\section{References}

[1] Brusselmans K., Vrolix R., Verhoeven G. and Swinnen J.V. (2005) Journal of Biological Chemistry, 280(7), 5636-5645.

[2] Claver I.P., Zhang, H., Li Q., Kexue Z. and Zhou H. (2010) Pakistan Journal of Nutrition, 9(4), 336-342. 
[3] Das A., Banik N. L. and Ray S.K. (2010) Cancer, 116, 164-176.

[4] Hama S.A., Al-Jaff B.M. and Mahmud B.M. (2009) Journal of Duhok University, 12(1), 312-316.

[5] Karimi G., Khoei A., Omidi A., Kalantari M., Babaei J., Taghiabadi E. and Razari B.M. (2009) Iranian Journal of Basic Medical Sciences, 13(2), 31-35.

[6] Lima E.M., Rissino J.D., Guimarães A.C., Overal D.J., Khayat A. S., Souza P.C., Christofolin D.M., Smith M.A. and Burbano R.R. (2005) Biology and Technology, 48(4), 537-540.

[7] Lim D.Y., Jeong Y., Tyner A.L. and Park J.H. (2007) American Journal Physiology of Gastrointestinal and Liver Physiology, 292, 66-75.

[8] Lepley D.M., Li B., Birt D.F. and Pelling J.C. (1996) Carcinogenesis, 17(11), 2367-75.

[9] Murthy N.S. and Mathew A. (2004) Current Science, 86(4), 518527.

[10]Ness B.D. and Knight J.A. (2004) Encyclopedia of Genetics, Salem Press, Inc. California, USA.

[11]Szliszka E., Czuba Z.P., Jernas K. and Krol W. (2008) International Journal of Molecular Sciences, 9, 56-64.

[12]Sulaiman K.M. (2000) The genetic and histological effects of Cigarette smoke on Albino laboratory mice Mus musculus, M.Sc. thesis, College of Education/ University of Salahaddin/ Erbil-Iraq.

[13]Sharma M.M., Singh A., Verma R.N., Ali D.Z. and Batra A. (2011) International Journal of Botany, 7(1), 103-107.

[14]Shubber E.K. and Juma A.S. (1999) The Nucleus, 42(3), 182187.

[15]Susan G.B., Voelki K.E., Anderson T.W. and Finn J. (1997) SPSS Guide to the New Statistical Analysis of Data, Springer, New York.

[16]Shukla S. and Gupta S. (2006) Molecular of Cancer Therapy, 5 (4), 843-852.

[17]Shukla S. and Gupta S. (2010) Pharmaceutical Research, 27 (6), 962-978.

[18]Talib W.H. and Mahasneh A.M. (2010) Scientia Pharmaceutica, $78,33-45$.

[19]Townsend C.C. and Guest E. (1966) Flora of Iraq, Ministry of Agriculture, Baghdad, Iraq, 2, 8-11.

[20]Zhong Y., Krisanapun C., Lee S.H., Nualsanit T., Sams C., Peungvicha P. and Baek S.J. (2010) European Journal of Cancer, 46(18), 3365-3374. 